\title{
El efecto del humo de sílice y el metacaolín en el proceso de envejecimiento de los morteros de cemento reforzados con fibras de vidrio (GRC)
}

\section{The effect of silica fume and metakaolin on glass-fibre reinforced concrete (GRC) ageing}

\author{
A. Enfedaque Díaz (*), L. Sánchez Paradela(*), V. Sánchez-Gálvez ${ }^{(*)}$
}

Recepción/Received: 16-IV-09

Aceptación/Accepted: 14-IX-10

Publicado online/Online publishing: 17-XII-10

\section{RESUMEN}

Para el uso del mortero de cemento reforzado con fibras de vidrio (GRC) en estructuras portantes se han de solucionar los problemas de reducción de las propiedades mecánicas que aparecen con el paso del tiempo. Estos problemas pueden ser solucionados mediante la adición de puzolanas o de metacaolín, a la pasta de mortero de cemento. Sin embargo, la cantidad de metacaolín que ha de ser añadida es elevada y el precio del GRC fabricado está fuera del mercado.

Se ha realizado una campaña experimental que analiza si la adición de humo de sílice o de metacaolín en proporciones reducidas consigue evitar o paliar el problema del envejecimiento, que supone un freno al uso del GRC en elementos estructurales.

Desgraciadamente, los resultados experimentales muestran que proporciones bajas de metacaolín o de humo de sílice no son efectivas para reducir el problema de pérdida de propiedades mecánicas.

Palabras clave: fibra de vidrio, mortero, durabilidad, envejecimiento, humo de sílice, puzolana.

\section{SUMMARY}

The deterioration of the mechanical properties of glassfibre reinforced concrete (GRC) over time rules out the use of this material in load-bearing structures. While one possible solution to this problem is the addition of pozzolans or metakaolin to the cement mortar, the amounts needed to ensure GRC integrity raise its price to non-competitive levels.

Experimental research has been conducted to analyze whether the addition of small amounts of silica fume or metakaolin can prevent or mitigate the ageing issue.

Unfortunately, the findings indicate that the addition of small proportions of metakaolin or silica fume to GRC are ineffective in improving its long-term performance.

Key words: glass fibres, mortar, durability, ageing, silica fume, pozzolan.

(*) Universidad Politécnica de Madrid.(Madrid, España). 


\section{INTRODUCCIÓN}

Los morteros de cemento reforzados con fibras de vidrio (GRC) son materiales compuestos de base cementícea que han sido usados en numerosas aplicaciones durante los últimos 40 años. Sus buenas propiedades mecánicas, su gran resistencia al fuego, la gran versatilidad de formas que puede adoptar y su resistencia a la corrosión lo hacen muy competitivo en la producción de paneles ligeros de fachada.

Por otro lado se emplea también como encofrado perdido, en tuberías, en la rehabilitación de edificios, en conducciones de alcantarillado, en recubrimiento de túneles, en protección de las riberas de los ríos y en barreras de protección acústica (1-6). En todos estos usos el GRC tiene una función no estructural.

En los últimos años, se ha pensado en el GRC como un material candidato para aplicaciones portantes, como son los suelos industriales, las cubiertas prefabricadas y las torres de comunicación (7-9). En todos estos usos el material empleado debe ser capaz de soportar esfuerzos importantes.

Sin embargo, la durabilidad de las fibras de vidrio en el entorno alcalino del cemento ha sido siempre una gran preocupación (10-15). A pesar del uso de fibras de vidrio resistentes a los entornos alcalinos (fibras de vidrio $A R$ ), los problemas de durabilidad todavía aparecen. Las propiedades mecánicas del GRC a largo plazo muestran una reducción de la resistencia a tracción y de la ductilidad del material. La fragilización del GRC, por tanto, ha supuesto un freno para el uso de este material para la producción de elementos portantes.

Desde que se identificó este problema, muchas investigaciones se han llevado a cabo para encontrar una solución. Entre las diferentes alternativas propuestas, la adición de un producto sintético derivado del caolín, llamado metacaolín, pareció ser la solución definitiva al problema (16-19). EI GRC fabricado con una adición de metacaolín se denomina Cem-FIL Star y muestra una mejora considerable de la resistencia a tracción y de la ductilidad en ensayos realizados sobre material envejecido mediante métodos acelerados. Estudios recientes afirman también que el humo de sílice y las cenizas volantes tienen una influencia positiva en el comportamiento de los morteros reforzados con fibras de vidrio $(20,21)$.

Desafortunadamente el precio del metacaolín es alto y las proporciones usadas (superiores al $25 \%$ respecto del peso de cemento) hacen que el material así logrado deje de ser económicamente rentable en numerosas aplicaciones. Por lo tanto su uso comercial no ha logrado un gran desarrollo.

\section{INTRODUCTION}

Glass-fibre reinforced concrete (GRC) is a cement-based material that has been used in numerous applications over the last 40 years. Its good mechanical performance, excellent fire and corrosion resistance and mouldability into a variety of shapes make it very competitive in the production of lightweight facade panels.

It is also used as permanent formwork, river bank protection and noise barriers, as well as in pipes, building rehabilitation, sewer pipelines and tunnel linings (1-6). None of these uses are structural.

In recent years, GRC has been considered for use in load-bearing applications such as industrial flooring, precasted roofing and communication towers (7-9), in which it would have to withstand significant stress.

The limited durability of glass fibres in an alkaline cement environment has always been a drawback (10-15), however, that not even the use of alkaliresistant (AR) fibres has been able to overcome. Over the long term, GRC tensile strength and ductility decline, making it unsuitable for use in the manufacture of loadbearing members.

Ever since this problem came to light, researchers have been studying possible ways to solve the problem. The alternatives proposed include the addition of a synthetic kaolin derivative known as metakaolin, which seemed to provide a permanent solution (16-19). Cem-FIL Star, a metakaolin-containing GRC, exhibits much improved tensile strength and ductility in accelerated ageing tests. Other recent studies have proven that silica fume and fly ash also have a beneficial effect on the behaviour of glass-fibre reinforced concrete $(20,21)$.

Unfortunately, metakaolin is costly and given the proportions needed to achieve the desired effect (over $25 \%$ by weight), the resulting material is not costeffective for many applications; therefore, it is not widely used commercially, despite the theoretical advances and the progress made in durability tests $(22,23)$. 
En consecuencia, y a pesar de los avances teóricos y en ensayos de durabilidad $(22,23)$, se ha pensado llevar a cabo un programa de investigación encaminado a analizar si pequeñas proporciones de aditivos inorgánicos pueden mejorar las propiedades mecánicas del GRC a largo plazo, manteniendo sin embargo el precio del material en niveles competitivos. Además se ha realizado un análisis de las superficies de fractura de las probetas de GRC ensayado a tracción para relacionar las diferencias de comportamiento entre las diferentes composiciones y su evolución con el paso del tiempo con la microestructura del material.

\section{PROGRAMA EXPERIMENTAL}

\subsection{Fabricación de paneles y preparación de probetas}

Todos los paneles se fabricaron con cemento Pórtland común (OPC) y fibras de vidrio AR. Estos dos materiales son la base principal de todas las formulaciones usadas.
As a result, a research programme was planned to analyze whether small amounts of inorganic admixtures could improve the long-term mechanical properties of GRC at a competitive price. The fracture surfaces of tensile-tested GRC specimens were also analyzed to determine whether a relationship can be drawn between behavioural differences over time among GRCs with a varying composition, and their respective microstructures.

\section{EXPERIMENTAL}

\subsection{Preparation of panels and test specimens}

All panels were made with ordinary Portland cement (OPC) and AR glass fibres, the two materials on which all formulations are based.

Tabla 1 / Table 1

Formulación paneles ensayados a flexión. Bending tests panel formulation.

\begin{tabular}{|c|c|c|c|c|c|}
\hline & $\mathbf{1 ( C )}$ & $\mathbf{2 ( M T K )}$ & $\mathbf{3 ( S F )}$ & $\mathbf{4 ( H S )}$ & $\mathbf{5 ( H S )}$ \\
\hline Cemento / Cement & 100 & 100 & 100 & 100 & 100 \\
\hline Arena / Sand & 100 & 100 & 100 & 100 & 100 \\
\hline Metacaolín / Metakaolín & - & 5 & - & - & - \\
\hline Humo de sílice / Silica fume & - & - & 1.5 & 5 & 10 \\
\hline Agua / Water & 40 & 40 & 40 & 40 & 40 \\
\hline Plastificante / Plasticizer & 0.8 & 0.8 & 0.8 & 0.8 & 0.8 \\
\hline Fibras de vidrio / Glass fibers & \multicolumn{7}{|c|}{ Fracción volumétrica / Volumetric fraction 5\% } \\
\hline
\end{tabular}

En la Tabla 1 se pueden apreciar los componentes usados y las proporciones utilizadas en la primera hormigonada. Con los paneles fabricados en esta hormigonada se realizaron ensayos a flexión del material.

Para cada una de las formulaciones usadas se fabricaron dos paneles con unas dimensiones aproximadas de 1.250 x $750 \mathrm{~mm}$ y con unos $10 \mathrm{~mm}$ de espesor. Todos los paneles se fabricaron mediante el proceso de proyección simultánea idéntico al empleado en la industria. Todos los componentes de la matriz de cemento se mezclaron previamente en una mezcladora giratoria. El mortero de cemento y las fibras de vidrio, de unos $36 \mathrm{~mm}$ de longitud, se proyectaron en los moldes hasta alcanzar el espesor indicado. Los paneles se compactaron pasando un rodillo helicoidal para lograr un buen contacto entre la pasta y el molde, para conseguir un buen contacto entre la pasta de cemento y las fibras y para eliminar las pequeñas burbujas de aire que hayan podido quedar atrapadas en la masa durante la proyección.
Table 1 shows the components and proportions used in the first batch of concrete, used in the panels made to conduct bending tests.

Two 10-mm thick panels measuring approximately $1250 \times 750 \mathrm{~mm}$ were made from each formulation with the simultaneous spray process commonly used in the industry. The cement matrix components were premixed in a rotary mixer, and the cement mortar and 36$\mathrm{mm}$ long glass fibres were sprayed into moulds to the thickness indicated. The panels were roller compacted to ensure proper contact between the cement paste and both the mould and the fibres, and to eliminate any entrained air. 
Los paneles se curaron en fábrica cubriéndolos con unas esteras húmedas durante las primeras 48 horas. Después de este tiempo los paneles se desencofraron y se almacenaron en una cámara climática durante 27 días a $20 \pm 1{ }^{\circ} \mathrm{C}$ a una humedad del $60 \pm 5 \%$. Después de este periodo los paneles se sacaron de la cámara climática y se cortaron con una sierra circular para obtener las probetas con unas dimensiones aproximadas de 275 x $50 \mathrm{~mm}$. De cada panel fabricado se obtuvieron 60 probetas. Posteriormente estas probetas se sumergieron en agua a $20^{\circ} \mathrm{C}$ durante 24 horas.

Después de este proceso de curado, 8 probetas de cada panel, elegidas aleatoriamente, la mitad cortadas en sentido longitudinal y la mitad cortadas en dirección transversal respecto de la dirección en la que se proyectó el material, se ensayaron a flexión en 4 puntos. Se eligieron otros grupos de 8 probetas, también de manera aleatoria que se sometieron a un proceso de envejecimiento acelerado por inmersión en agua caliente a $50^{\circ} \mathrm{C}$.

A la vista de los resultados obtenidos en los ensayos de flexión se decidió ampliar el trabajo y realizar una segunda hormigonada con diferentes proporciones de aditivos para realizar ensayos de tracción. Las formulaciones y aditivos empleados se pueden ver en la Tabla 2. Se fabricaron dos tipos diferentes de paneles de cada una de las formulaciones. Las dimensiones de los paneles fueron de $1.200 \times 1.200$ y de 1.100 x $600 \mathrm{~mm}$. La longitud de las fibras empleadas en esta segunda hormigonada es la misma que en la primera hormigonada. La fracción volumétrica de fibras es también del 5\%. El proceso de fabricación fue similar al empleado en la primera hormigonada.
Curing was conducted at the plant, covering the panels with moist matting for the first 48 hours. After this initial period, the forms were demouldedand the panels were stored in an climatic chamber for 27 days at $20 \pm 1^{\circ} \mathrm{C}$ and $60 \pm 5 \%$ relative humidity. When the panels were removed from the chamber, 60 test specimens, each measuring approximately $275 \times 50 \mathrm{~mm}$, were cut from each panel with a circular saw. The test specimens were then immersed in water at $20^{\circ} \mathrm{C}$ for 24 hours.

After curing, four-point bending tests were conducted on eight randomly selected specimens from each panel, half of which were cut in the spraying direction and the other half crosswise to that direction. Other groups of eight specimens were also chosen at random for accelerated ageing by immersion in hot water $\left(50^{\circ} \mathrm{C}\right)$.

In light of the results of the bending tests, a second batch of GRCs with different admixture proportions was prepared for tensile testing. The compositions and admixtures used are given in Table 2. Two sizes of panels, $1200 \times 1200$ and $1100 \times 600 \mathrm{~mm}$, were made from each formulation. The length and volume of the fibres (5\% of the mix) in this second batch was the same as in the first and a similar procedure was followed to prepare the cement mortar.

Tabla 2 / Table 2

Formulación paneles ensayados a tracción. Tensile tests panel formulation.

\begin{tabular}{|c|c|c|c|c|}
\hline & Control / Control & Metacaolín / Metakaolin & H. sílice / Silica fume 10\% & H. sílice / Silica fume 20\% \\
\hline Cemento / Cement & 50 & 50 & 50 & 50 \\
\hline Arena / Sand & 50 & 50 & 50 & 50 \\
\hline Metacaolín / Metakaolin & - & 5 & - & - \\
\hline Humo de sílice / Silica fume & - & - & 5 & 10 \\
\hline Agua / Water & 21 & 26 & 27 & 33 \\
\hline Plastificante / Plasticizer & 0.5 & 0.5 & 0.5 & 0.5 \\
\hline Fibras de vidrio / Glass fibers & \multicolumn{4}{|c|}{ Fracción volumétrica / Volumetric fraction 5\% } \\
\hline
\end{tabular}

Se dejó fraguar el material a la intemperie durante las 24 horas siguientes a la fabricación. Posteriormente se desencofraron y se almacenaron los paneles en una cámara climática con la temperatura fija en $20 \pm 1{ }^{\circ} \mathrm{C}$ y una humedad del $98 \%$. El material fue almacenado durante 28 días en la cámara climática hasta su ensayo. Se realizó el corte de las probetas rectangulares de 300 x 50 mm a partir de las placas almacenadas. Un grupo de 24 probetas de cada formulación fue sometido posteriormente al proceso de envejecimiento acelerado mediante inmersión en agua caliente a $50^{\circ} \mathrm{C}$, de forma similar al proceso seguido con las probetas de la primera hormigonada.
By contrast, in this case the material was moulded and allowed to set outdoors for 24 hours, after which the forms were demoulded and the panels were stored for 28 days in an climatic chamber at a constant $20 \pm 1^{\circ} \mathrm{C}$ and $98 \%$ relative humidity. Rectangular test specimens measuring $300 \times 50 \mathrm{~mm}$ were cut from these panels, and 24 specimens of each formulation were subjected to accelerated ageing by the same hot water $\left(50^{\circ} \mathrm{C}\right)$ immersion procedure as in the first batch. 


\subsection{Ensayos de flexión en cuatro puntos}

Se realizaron una serie de ensayos de flexión en cuatro puntos siguiendo las recomendaciones que se establecen en la Norma Europea EN 1170 (24). En la Figura 1 se puede observar un esquema del ensayo y en la Figura 2 se puede ver un momento del mismo. Los ensayos de flexión se realizaron en una máquina universal de ensayos

\subsection{Four-point bending tests}

A series of four-point bending tests was conducted in accordance with the recommendations set out in European Standard EN 1170 (24). Figure 1 shows a diagram of the test set-up and Figure 2 a photograph taken during the test. The bending tests were performed on an INSTRON universal testing machine with a

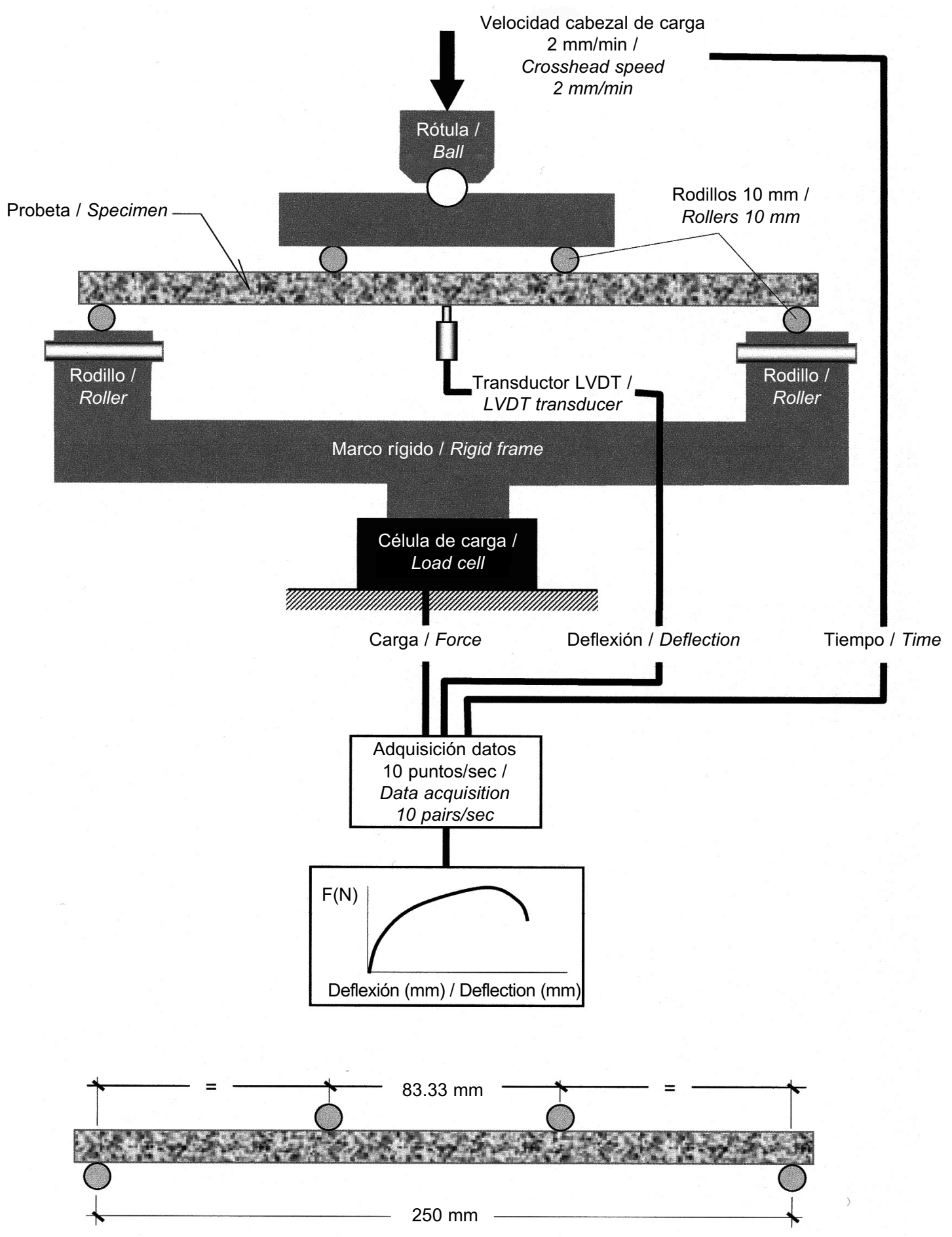

Figura 1. Esquema ensayo de flexión en 4 puntos. Figure 1. Four point bending test sketch. 


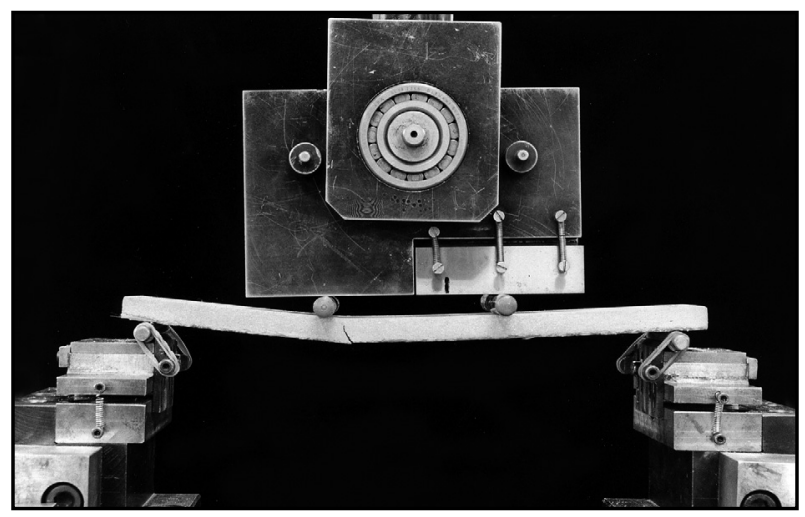

Figura 2. Ensayo de flexión en 4 puntos.

Figure 2. Four point bending test.

INSTRON de 100 kN de capacidad máxima de carga. Se impuso una velocidad de desplazamiento de la cabeza de carga de $2 \mathrm{~mm} / \mathrm{min}$ en todos los ensayos realizados.

Se diseñó y fabricó un cabezal de carga que permitía una rotación perfecta de los rodillos que evitaba la localización del daño de la probeta aún cuando existieran diferencias de espesor en la misma.

La máquina de ensayos se equipó con una célula de carga capaz de registrar cargas de hasta $1 \mathrm{~N}$. La deflexión de la probeta durante el ensayo se midió a través de un transductor LVDT que registró las medidas con un error máximo de $5 \mu \mathrm{m}$. La carga y la deflexión se registraron a través de un sistema de adquisición de datos HewlettPackard cada décima de segundo.

\subsection{Ensayos de tracción simple}

Las características de los ensayos de tracción han sido previamente explicadas en la literatura (29). Los ensayos se realizaron con control de desplazamiento a una velocidad de $1 \mathrm{~mm} / \mathrm{min}$, registrándose la carga mediante una célula de carga y la deformación mediante dos extensómetros. Éstos se colocaron a ambos lados de la misma para registrar las posibles flexiones que pudieran introducirse durante el ensayo. Se amplió la base de medida de los extensómetros para aumentar la probabilidad de que la fractura del material se produjera en la zona situada entre las cuchillas.

\subsection{Envejecimiento acelerado del material}

El envejecimiento del material se ha realizado mediante la inmersión en tanques de agua mantenida a $50{ }^{\circ} \mathrm{C}$. El método de envejecimiento está basado en la hipótesis que afirma que la inmersión del material en agua caliente durante cortos periodos de tiempo permite predecir las propiedades mecánicas del material después de largos periodos de exposición a la intemperie. Esta hipótesis se ha comprobado comparando ensayos realizados maximum load capacity of $100 \mathrm{kN}$. A crosshead speed of $2 \mathrm{~mm} / \mathrm{min}$ was applied in all tests.

The crosshead design enabled the rollers to turn freely, thus preventing localized damage, even to the specimens with different thicknesses.

The testing machine was equipped with a load cell able to record loads to a precision of $1 \mathrm{~N}$. Specimen deflection during testing was measured by an LVDT transducer with a maximum error of $5 \mu \mathrm{m}$. Load and deflection values were recorded every tenth of a second with a Hewlett-Packard data acquisition system.

\subsection{Tensile tests}

A description of the tensile tests can be found in the literature (29). These tests were conducted at a controlled speed of $1 \mathrm{~mm} / \mathrm{min}$. The load was recorded by a load cell and one strain gauge was placed on each side of the sample to detect and record any bending that might take place during the test. The measurement base of the strain gauges was enlarged to increase the likelihood of material breakage in the area between their blades.

\subsection{GRC accelerated ageing}

The material was aged by immersion in water tanks at a constant $50^{\circ} \mathrm{C}$. This method is based on the hypothesis that the mechanical properties of GRC can be predicted after long-term exposure to the elements by immersion in hot water for short periods. This hypothesis has been verified by comparing tests conducted on material subjected to accelerated ageing and material left outdoors for extended periods. These tests, conducted 
sobre material envejecido aceleradamente y sobre material dejado a la intemperie durante largos periodos de tiempo. Estas comparaciones se han realizado para el clima del Reino Unido (25) donde se ha hallado que 1 día de inmersión en agua caliente a $50^{\circ} \mathrm{C}$ es equivalente a 101 días de exposición a la intemperie.

Posteriormente, se han encontrado otra serie de equivalencias para diferentes climas, aunque ciertos autores han señalado discrepancias al establecer esta equivalencia (26-28).

A pesar de esto, el envejecimiento del GRC mediante la inmersión en agua caliente es el proceso que se utiliza de forma más generalizada. Por lo tanto, en este estudio, ha sido el método usado.

Se introdujeron los diferentes grupos de 8 probetas de la primera hormigonada en baños de agua caliente mantenida a $50{ }^{\circ} \mathrm{C}$ durante periodos de 4,8 y 12 semanas. Después del proceso de envejecimiento, las probetas se sacaron de los baños con agua a $50^{\circ} \mathrm{C}$ y se introdujeron en baños con agua a $20{ }^{\circ} \mathrm{C}$ durante 24 horas antes de ser ensayadas a flexión en cuatro puntos.

De igual forma, las probetas de la segunda hormigonada se almacenaron en baños con agua a $50{ }^{\circ} \mathrm{C}$ durante 40 , 80 y 120 días. Posteriormente fueron almacenadas en una cámara climática a $20{ }^{\circ} \mathrm{C}$ y $98 \%$ de humedad hasta ser ensayadas a tracción.

\subsection{Resultados experimentales de los ensayos de flexión}

En la Figura 3 se puede ver la curva tensión-deflexión que se obtuvo en las probetas de flexión ensayadas a 28 días. Aunque el comportamiento depende del espesor de for the conditions prevailing in the United Kingdom (25), showed that one day of immersion in water at $50^{\circ} \mathrm{C}$ is equivalent to 101 days of exposure to the elements.

Another series of relationships was subsequently established for other climates, although certain authors have identified discrepancies in the findings (26-28).

That notwithstanding, GRC ageing by immersion in hot water is the procedure most widely accepted and was therefore used in this study.

The groups of eight test specimens taken from the first batch were placed in water baths at a constant temperature of $50{ }^{\circ} \mathrm{C}$ for four, eight and 12 weeks and subsequently transferred to other baths with a water temperature of $20^{\circ} \mathrm{C}$ for 24 hours before undergoing the four-point bending tests.

Similarly, the second batch of test specimens was kept in baths with a water temperature of $50^{\circ} \mathrm{C}$ for 40,80 and 120 days and later stored in an environmental chamber at $20^{\circ} \mathrm{C}$ and $98 \%$ relative humidity until the tensile tests were conducted.

\subsection{Bending test results}

Figure 3 shows the stress-deflection curve found for the 28-day specimens tested for flexural strength. While specimen behaviour was found to depend on thickness,

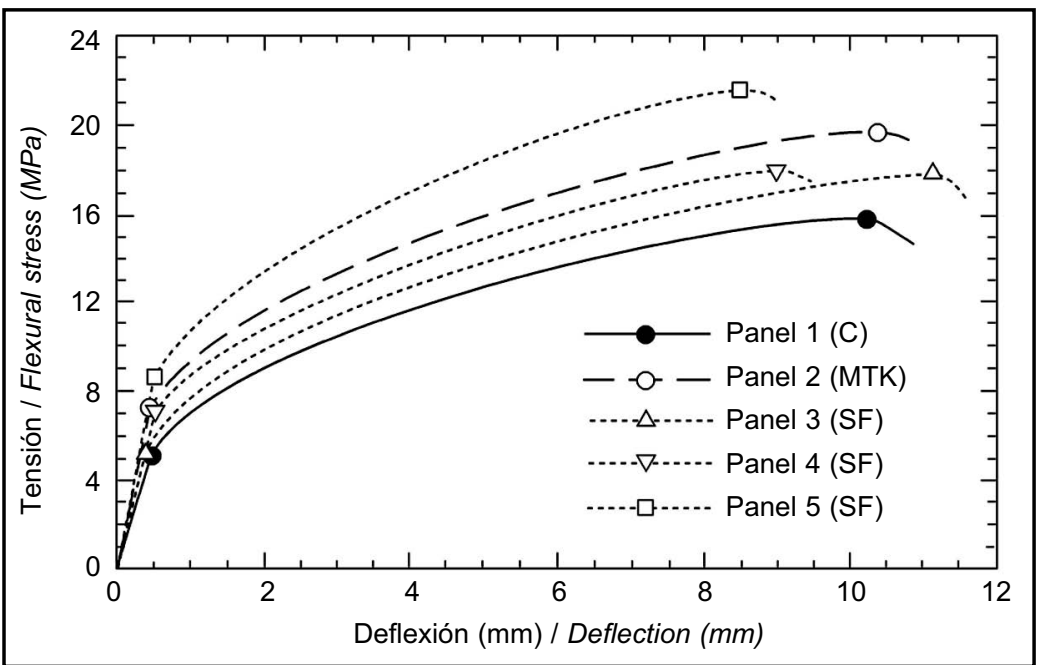

Figura 3. Curvas tensión deformación obtenidas en ensayos de flexión. Figure 3. Stress-strain bending curves. 
las probetas, y éste cambia ligeramente de unas probetas a otras, se puede observar còmo el comportamiento del las diferentes muestras es comparable.

Por otro lado las Tablas 3 y 4 resumen los resultados experimentales para muestras jóvenes y envejecidas en todas las formulaciones ensayadas. Estas tablas ilustran la evolución del Modulo de Rotura (MOR) y de la deformación de rotura del material, siendo ambos parámetros obtenidos según las indicaciones de la Norma Europea mencionada anteriormente (24).

Como se puede ver la tensión de rotura del material baja con el paso de tiempo en todas las formulaciones ensayadas.

La reducción de la deformación de rotura es todavía más importante, y hay que resaltar que no se han hallado diferencias apreciables entre las diferentes formulaciones empleadas. which varied slightly from one sample to the next, all samples were observed to perform comparably.

Tables 3 and 4 summarize the experimental results for unaged and aged samples for all the compositions tested. These tables illustrate the variations in the modulus of rupture (MOR) and failure strain parameters, both of which were found as specified in the aforementioned European standard (24).

The results showed that there is a decline in the maximun stress that the samples bear over time for all the compositions tested

The drop in the failure strain values was even more significant, while no perceptible differences were observed in this regard among the formulations used.

Tabla 3 / Table 3

Resistencia a flexión (MOR) Mpa.

Flexural Strength (MOR) Mpa.

\begin{tabular}{|c|c|c|c|c|c|}
\hline & & Joven / Unaged & 4 Semanas / Weeks & 8 Semanas / Weeks & 12 Semanas / Weeks \\
\hline \multirow{3}{*}{$1(\mathrm{C})$} & Media / Average & 15.7 & 14.1 & 13.1 & 11.2 \\
\cline { 2 - 6 } & Desv. Tip / Std. Dev. & 2.0 & 2.1 & 1.8 & 1.4 \\
\hline \multirow{2}{*}{$2(\mathrm{MTK})$} & Media / Average & 19.6 & 12.8 & 11.4 & 10.8 \\
\cline { 2 - 6 } & Desv. Tip. / Std. Dev. & 2.7 & 2.8 & 1.5 & 1.2 \\
\hline \multirow{2}{*}{$3(\mathrm{SF})$} & Media / Average & 17.9 & 12.65 & 1.4 & 9.6 \\
\cline { 2 - 6 } & Desv. Tip. / Std. Dev. & 1.2 & 1.2 & 1.3 & 1.4 \\
\hline \multirow{2}{*}{$4(\mathrm{SF})$} & Media / Average & 17.8 & 1.7 & 0.8 & 11.1 \\
\cline { 2 - 6 } & Desv. Tip. / Std. Dev. & 2.4 & 15.6 & 13.0 & 1.8 \\
\hline \multirow{2}{*}{$5(\mathrm{SF})$} & Media / Average & 21.5 & 2.3 & 2.8 & 11.2 \\
\cline { 2 - 6 } & Desv. Tip. / Std. Dev. & 3.0 & & & 1.9 \\
\hline
\end{tabular}

Tabla 4 / Table 4

Deformación a flexión $\left(x 0^{-3}\right)$. Flexural Strain $\left(x 10^{-3}\right)$.

\begin{tabular}{|c|c|c|c|c|c|}
\hline & & Jóvenes & 4 Semanas / Weeks & 8 Semanas / Weeks & 12 Semanas / Weeks \\
\hline \multirow{2}{*}{$1(\mathrm{C})$} & Media / Average & 10.2 & 8.35 & 5.7 & 3.4 \\
\hline & Desv. Tip / Std. Dev. & 1.3 & 1.1 & 0.8 & 0.7 \\
\hline \multirow{2}{*}{ 2(MTK) } & Media / Average & 10.0 & 4.9 & 2.1 & 1.3 \\
\hline & Desv. Tip. / Std. Dev. & 1.5 & 0.8 & 0.9 & 0.5 \\
\hline \multirow{2}{*}{$3(\mathrm{SF})$} & Media / Average & 10.5 & 6.8 & 2.9 & 2.1 \\
\hline & Desv. Tip. / Std. Dev. & 1.2 & 0.6 & 0.6 & 0.9 \\
\hline \multirow{2}{*}{$4(S F)$} & Media / Average & 9.4 & 8.1 & 6.8 & 3.8 \\
\hline & Desv. Tip. / Std. Dev. & 1.4 & 1.1 & 1.2 & 1.1 \\
\hline \multirow{2}{*}{$5(\mathrm{SF})$} & Media / Average & 10.1 & 6.1 & 3.9 & 2.8 \\
\hline & Desv. Tip. / Std. Dev. & 1.7 & 1.3 & 1.5 & 1.1 \\
\hline
\end{tabular}

\subsection{Ciclos hielo-deshielo y húmedo-seco}

El programa experimental incluyó también el análisis del envejecimiento del GRC mediante ciclos húmedo-seco y hielo-deshielo. Teniendo en cuenta los resultados obtenidos después del envejecimiento mediante inmersión en

\subsection{Freeze-thaw and wet-dry cycles}

The experimental programme also included an analysis of GRC ageing when subjected to wet-dry and freezethaw cycles. In light of the results obtained after hotwater ageing, the study was broadened to analyze the 
agua caliente, se decidió analizar la influencia del método de envejecimiento en una de las placas de control fabricadas.

Se realizaron ciclos de humedecido y secado en diferentes grupos de 8 probetas. Éstas se almacenaron en tanques de agua a $20^{\circ} \mathrm{C}$ durante 24 horas y posteriormente se almacenaron durante 24 horas a $70{ }^{\circ} \mathrm{C}$ de temperatura. Se ensayaron estas probetas después de 10,25 y 50 ciclos.

Los ciclos de hielo-deshielo se realizaron también en diferentes grupos de 8 probetas que se mantuvieron durante 7 horas en agua a $20^{\circ} \mathrm{C}$ almacenadas posteriormente durante 5 horas en aire a $-20^{\circ} \mathrm{C}$. Las probetas se ensayaron después de 50, 100 y 200 ciclos.

Los resultados experimentales se muestran resumidos en las Figuras 4 y 5 . Como se puede ver, en ambos tipos de ciclos se produce una fragilización del GRC similar a la que se produjo mediante la inmersión del GRC en agua caliente. La tensión máxima que alcanza el material después de 50 ciclos de humedecido-secado y después de 200 ciclos de hielo-deshielo es comparable a la obtenida después de 12 semanas de envejecimiento mediante inmersión en agua caliente. Sin embargo, la evolución con el tiempo muestra comportamientos diferentes. La deformación de rotura baja rápida y continuadamente con los ciclos húmedos-secos. Esta reducción con el tiempo tiene menor influencia cuando se usan los ciclos hielo-deshielo.

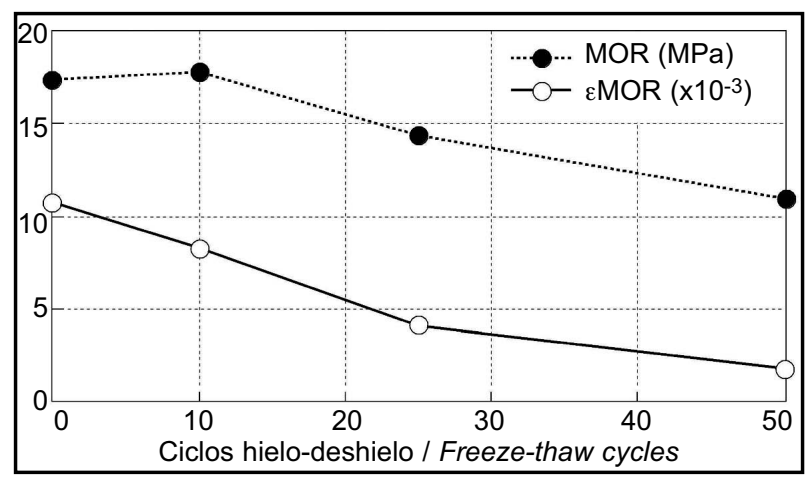

Figura 4. Evolución del MOR con los ciclos hielo-deshielo. Figure 4. Evolución del MOR con los ciclos hielo-deshielo.

\subsection{Resultados experimentales de los ensayos de tracción}

A la vista de los resultados obtenidos en los ensayos de flexión se decidió aumentar las proporciones de adiciones empleadas y comprobar la influencia de las mismas mediante ensayos de tracción simple. En la Figura 6 se muestra los resultados de los ensayos de tracción realizados en probetas de GRC con $10 \%$ de metacaolín. En la literatura se muestran los resultados obtenidos para el resto de formulaciones (29). effect of the ageing method chosen on one of the control panels.

Groups of eight specimens were subjected to wet and dry cycles, consisting of immersion in water at $20^{\circ} \mathrm{C}$ for 24 hours, followed by storage in air at $70^{\circ} \mathrm{C}$ for another 24 hours. The specimens were tested after 10, 25 and 50 cycles.

Groups of eight test specimens were also subjected to freeze-thaw cycles: they were first kept in water at $20^{\circ} \mathrm{C}$ for seven hours and then removed and stored in air for 5 hours at a temperature of $-20^{\circ} \mathrm{C}$. The specimens were tested after 50, 100 and 200 cycles.

The experimental results are summarized in Figures 4 and 5. As the figures show, the GRC grew brittle in both types of cycles, just as it did after immersion in hot water. The maximum stress level after 50 wet-dry and 200 freeze-thaw cycles was comparable to the level found after 12 weeks of hot-water ageing. The pattern of variation over time differed, however. While the failure strain values dropped steadily and quickly as the wet-dry cycles progressed, the decline was less pronounced in the freeze-thaw cycles.

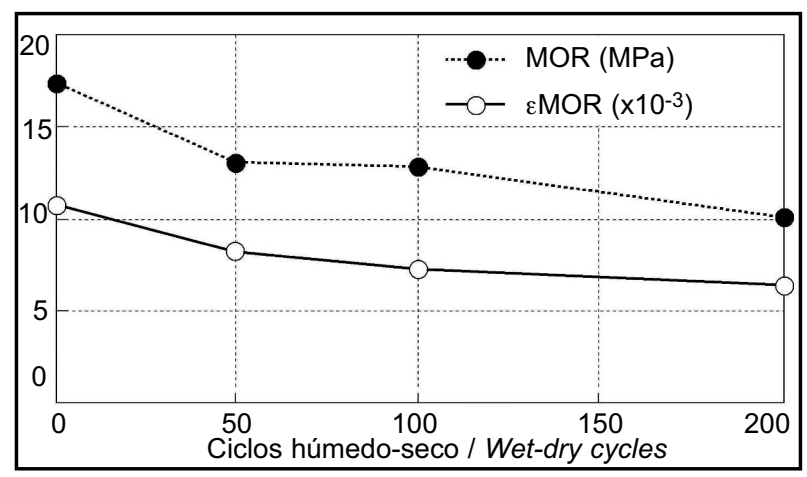

Figura 5. Evolución del MOR con los ciclos húmedo-seco. Figure 5. MOR evolution with wet-dry cycles.

\subsection{Tensile test results}

On the grounds of the bending test results, the proportion of the additions used was raised and tensile tests were conducted to ascertain the possible effects. Figure 6 shows the results of the tensile tests performed on GRC specimens containing $10 \%$ metakaolin. The literature describes the findings for the other formulations (29). 
El comportamiento del material joven en todas las formulaciones está compuesto de dos ramas diferentes. El GRC tiene un comportamiento elástico y lineal hasta que se alcanza el límite de proporcionalidad (LOP), a partir de este punto el material tiene un comportamiento pseudoplástico que corresponde a un fenómeno de fisuración múltiple. Durante esta fase aparecen fisuras que comienzan a abrirse hasta que su crecimiento se detiene cuando encuentran una zona del material capaz de soportar la concentración de tensiones que éstas crean. La carga aumenta un poco y es en otro punto del material donde aparece otra fisura, crece y para su crecimiento hasta que llegado un momento el material se fractura a partir de la fisura más débil.

Sin embargo, se observaron variaciones de comportamiento en el material joven: el metacaolín mejora las propiedades del material a corto plazo, el GRC con un $10 \%$ de humo de sílice tiene peores características mecánicas que el material de control y un contenido de humo de sílice del $20 \%$ no produce variaciones significativas en las propiedades mecánicas del GRC respecto a la formulación sin adiciones.

Después de 40 días de envejecimiento acelerado, la curva tensión-deformación muestra que la rama de pseudoplasticidad se ha reducido drásticamente en todas las formulaciones estudiadas. La deformación de rotura del GRC con un $10 \%$ de metacaolín es tan sólo un $25 \%$ de la que mostraba el material joven pero sigue siendo notablemente superior a la formulación de control y la tensión de rotura es igual a la de la formulación de control. Las características mecánicas del GRC fabricado con

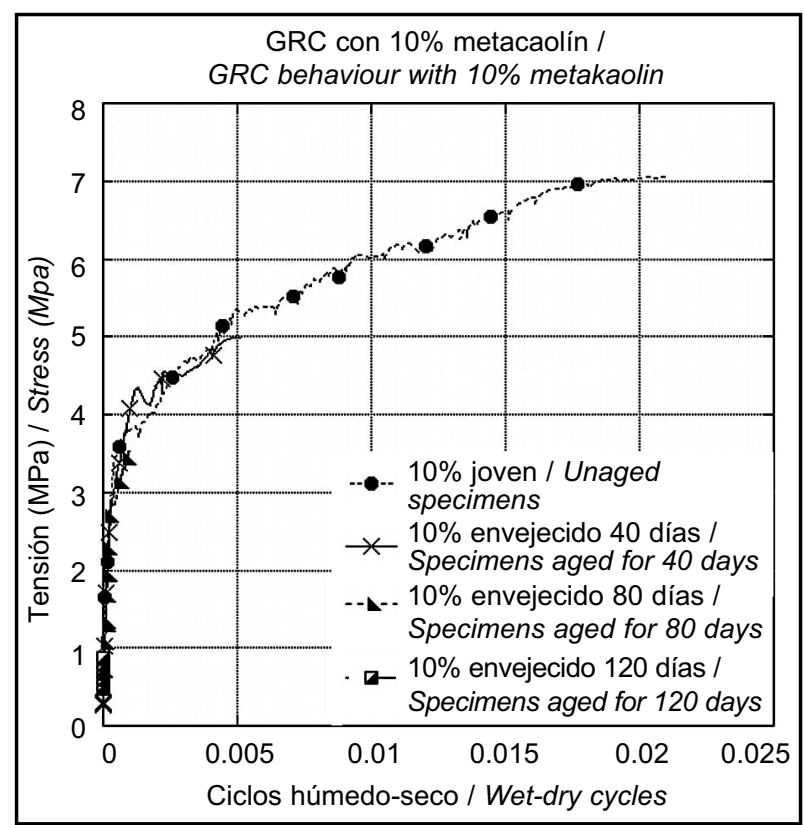

Figura 6. Curva tensión-deformación de un ensayo de tracción de GRC con $10 \%$ de metacaolín.

Figure 6. GRC with $10 \%$ metakaolin tensile stress-strain curve.
The unaged GRC exhibited two distinct behaviour patterns in all formulations: elastic and linear up to the limit of proportionality (LOP), and pseudo-plastic thereafter, associated with multiple cracking. During the latter stage, cracks appeared and widened until they reached an area in the material that was able to withstand the concentrated stresses generated. A slight increase in the load led to cracking in a different part of the material, which was likewise eventually contained. Successive increases eventually led to failure at the weakest point in the material.

The unaged material behaved differently: metakaolin improved its short-term properties, while the GRC with $10 \%$ silica fume exhibited poorer mechanical properties than the control material. A $20 \%$ silica fume content, in turn, led to no significant changes in GRC strength compared to the unadditioned material.

After 40 days of accelerated ageing, the pseudo-plastic area of the stress-strain curve narrowed drastically in all the formulations analyzed. The failure strain found for the GRC with $10 \%$ metakaolin was only $25 \%$ of the value for the unaged material, but still significantly higher than for the control formulation. The breaking stress, in turn, was the same as in the control material. While the aged GRC containing $10 \%$ silica fume was not as strong as the aged formulation, performance

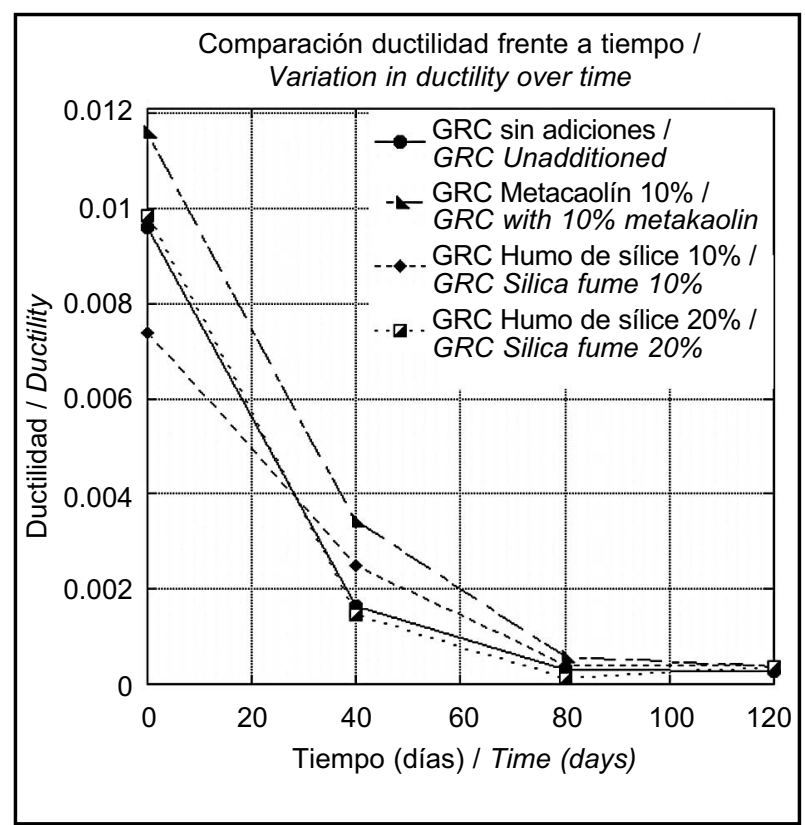

Figura 7. Evolución de la ductilidad con el paso del tiempo. Figure 7. Evolution of GRC ductility with time. 
un $10 \%$ de humo de sílice y envejecido son peores que las del GRC de control después del envejecimiento. El comportamiento del GRC fabricado con un $20 \%$ de humo de sílice sigue siendo similar al GRC sin adiciones.

Después de 80 días de envejecimiento todas las formulaciones estudiadas, excepto la que incluye metacaolín, muestran un comportamiento que se limita a su rama elástica y por tanto la curva tensión-deformación termina en el LOP. El comportamiento de las probetas fabricadas con metacaolín tiene una rama elástica y le sigue una rama de multifisuración de reducidas dimensiones.

El comportamiento de las probetas envejecidas durante 120 días es igual al observado en las probetas envejecidas 80 días. Las probetas fabricadas con un $10 \%$ de metacaolín han perdido por completo el comportamiento posterior al LOP.

En la Figura 7 se puede ver la evolución de la ductilidad del material con el tiempo de envejecimiento acelerado.

\section{ESTUDIO FRACTOGRÁFICO DE LAS PROBETAS ENSAYADAS A TRACCIÓN}

Los ensayos a tracción realizados sobre probetas rectangulares mostraron los diferentes comportamientos que tienen las distintas formulaciones de GRC. Mediante el estudio de las superficies de fractura se intentó hallar las causas de estas diferencias de comportamiento.

El estudio de las superficies de fractura se realizó usando un microscopio electrónico de barrido (Scanning Electronic Microscope). En la Figura 8 se muestra una probeta ensayada a tracción. La superficie de fractura ha sido dividida en tres zonas. Se estudió la zona central de la misma para evitar los efectos de borde que han podido aparecer en las zonas laterales de las probetas. was similar in the material made with $20 \%$ silica fume and the unadditioned GRC.

All the specimens exposed to accelerated ageing for 80 days, except the ones containing metakaolin, exhibited elastic behaviour only; consequently, their stress-strain curves ended at the LOP. The curve for the test specimens manufactured with metakaolin exhibited elastic behaviour followed by multiple cracking, followed by a short pseudoplastic zone where multicracking takes place.

The 120-day aged specimens behaved in much the same way as their 80-day counterparts. Here, however, the curves for the samples manufactured with $10 \%$ metakaolin also ended at the LOP.

The variation in material ductility is plotted against time of exposure to accelerated ageing in Figure 7.

\section{FRACTOGRAPHIC ANALYSIS OF TENSILE-TESTED SPECIMENS}

The tensile tests conducted on the rectangular specimens revealed that the various GRC formulations behaved differently. The fracture surfaces were studied with a scanning electron microscope in an effort to discover the causes of these differences in behaviour.

Figure 8 shows a tensile-tested specimen. The fracture surface was divided into three areas. The central portion was chosen for the study to rule out any edge effects that might have appeared in the outer areas of the specimens.

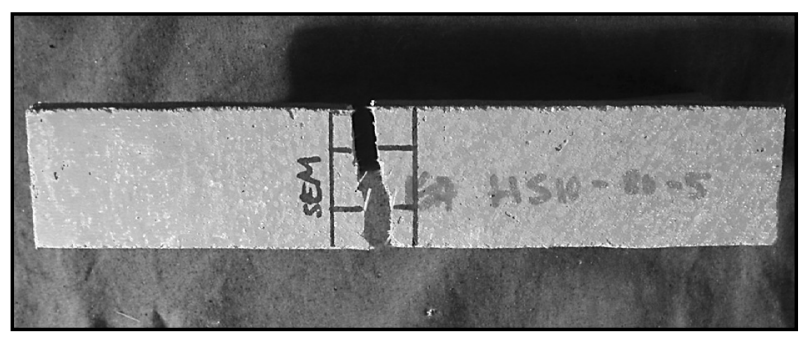

Figura 8. Probeta fracturada.

Figure 8. Broken test specimen.

Las Figuras 9 y 10 muestran micrografías del material joven. La fractura se produce de forma análoga para todas las formulaciones ensayadas. Se aprecia que prácticamente todas las fibras han sido arrancadas y que, por tanto, los filamentos de las fibras de vidrio están enteros.
Figures 9 and 10 show micrographs of the unaged material, which fractured in a similar manner in all the formulations tested. Note that nearly all the glass fibres pulled out of the matrix with their filaments intact. The fracture surfaces are very jagged, indicative of the 


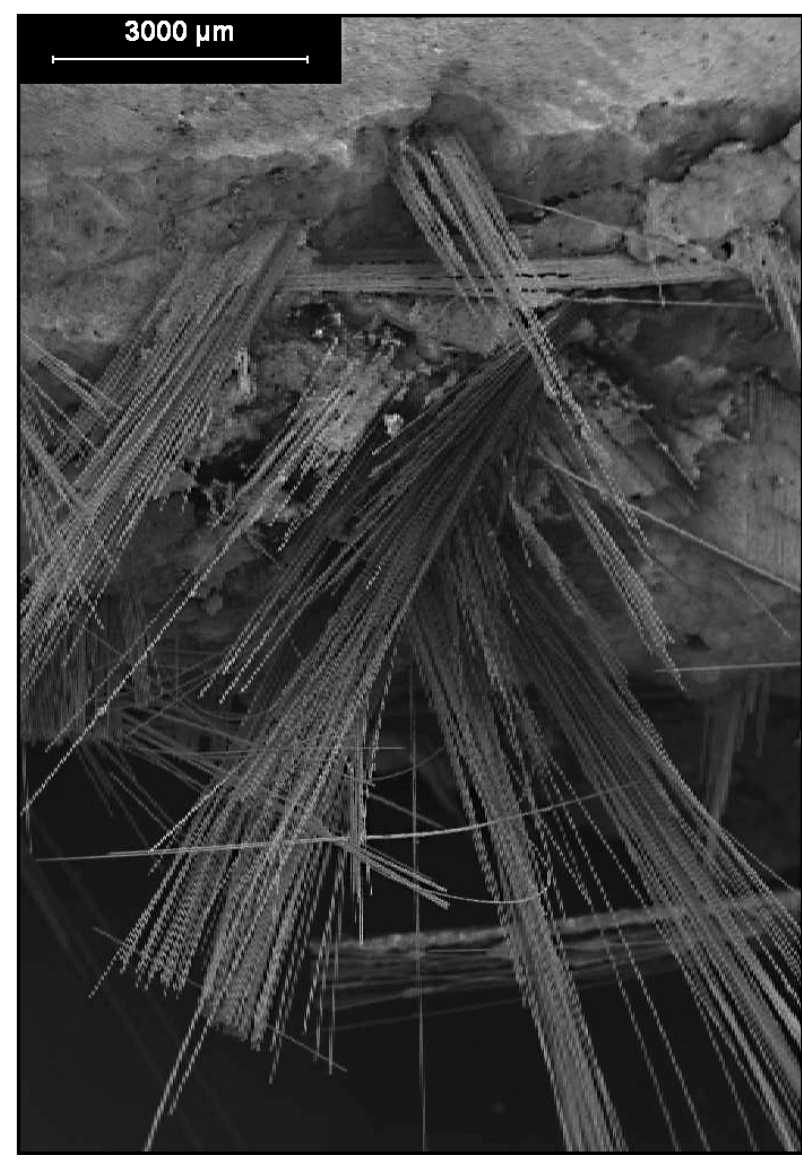

Figura 9. GRC joven con $10 \%$ humo de sílice. Figure 9. Unaged GRC with $10 \%$ silica fume.

Las superficies de fractura son muy abruptas; esto es reflejo del proceso de fisuración y fractura que se produce en el material joven y que se corresponde con el fallo gradual del material en la rama de fisuración múltiple que aparece en la curva tensión-deformación como un comportamiento pseudo-plástico. Las imágenes tomadas de las probetas fabricadas con el resto de formulaciones muestran superficies de fractura con características similares. No se aprecian grandes diferencias ni en el número de fibras rotas ni en la cantidad de fibras arrancadas.

En las Figuras 11 y 12 se muestran fractografías obtenidas a partir de las muestras envejecidas 40 días en agua caliente.

Las superficies de fractura que se ven en estas figuras son mucho más regulares, la topografía muestra pocos entrantes y salientes. Hay una reducción del número de fibras arrancadas de la matriz y se observa un buen número de fibras rotas, estando éstas fracturadas al ras de la superficie de fractura de la matriz cementícea. Las muestras ensayadas con un $10 \%$ de metacaolín tienen un menor número de fibras rotas que el resto de las composiciones de GRC estudiadas (Figura 12).

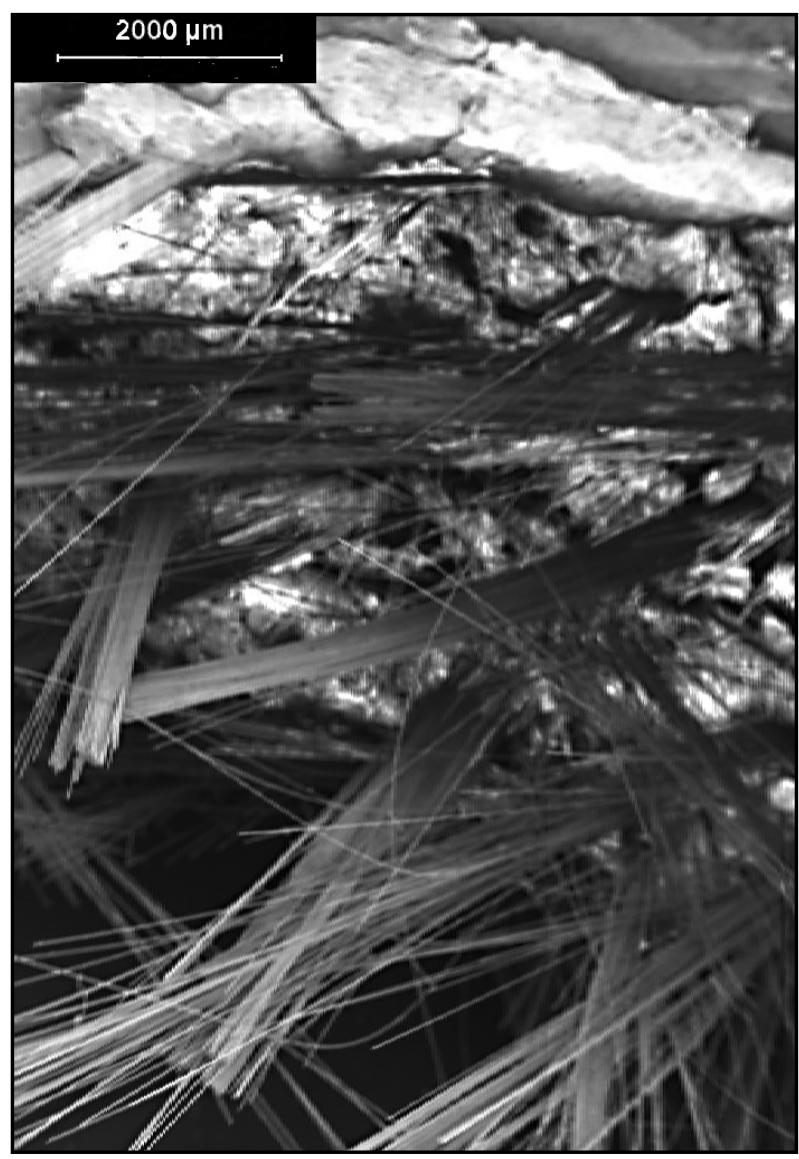

Figura 10. GRC joven sin adiciones.

Figure 10. Unaged, unadditioned GRC.

cracking and fracture process that took place in the unaged material that in turn denoted the gradual GRC failure in the pseudo-plastic, multiple cracking segment of the stress-strain curve. The fracture surfaces of the test specimens manufactured with the other formulations were similar. No major differences were observed in the number of broken or pulled-out fibres.

Figures 11 and 12 are fractographs of the 40-day specimens aged with hot water.

The fracture surfaces in these figures were much straighter, with a smaller number of recesses and protruding edges. Fewer fibres pulled out of the cement matrix, while a substantial number broke flush with the fracture surface of the matrix. The samples with $10 \%$ metakaolin had fewer broken fibres than the other GRC compositions analyzed (Figure 12). 


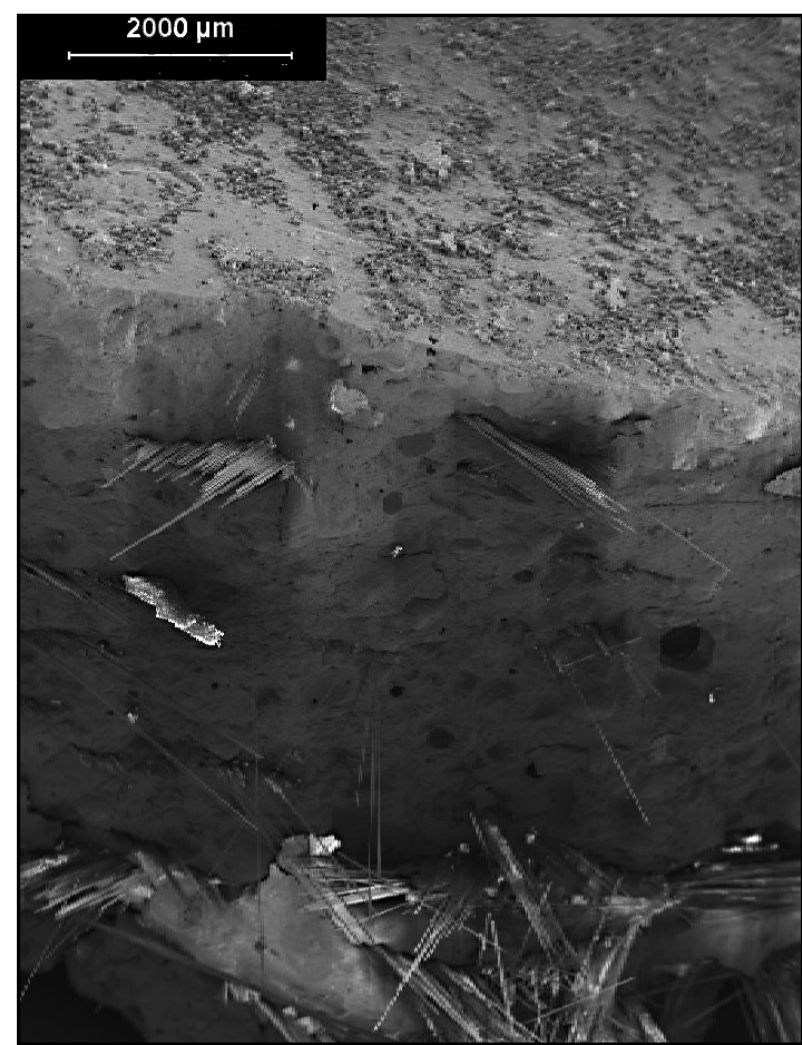

Figura 11 . GRC con $20 \%$ humo de sílice envejecido durante 40 días.

Figure 11. 40-day aged GRC with $20 \%$ silica fume.

Las micrografías de las muestras rotas, después de un envejecimiento de 80 días, se pueden ver en la Figuras 13 y 14.

En estas micrografías vuelven a reproducirse las características que ya han sido citadas en los casos de las probetas envejecidas durante 40 días. Las superficies de fractura de las probetas envejecidas 80 días son aún más lisas. Se ha producido un leve aumento del número de fibras rotas. En las probetas ensayadas con metacaolín aparecen menos fibras rotas que en el resto de formulaciones. Sin embargo, el número de fibras arrancadas en las probetas fabricadas con metacaolín y envejecidas durante 80 días es menor que las que se observaron en probetas con la misma composición envejecidas durante 40 días.

En las probetas envejecidas 120 días se corroboran los fenómenos observados en el GRC envejecido 40 y 80 días.

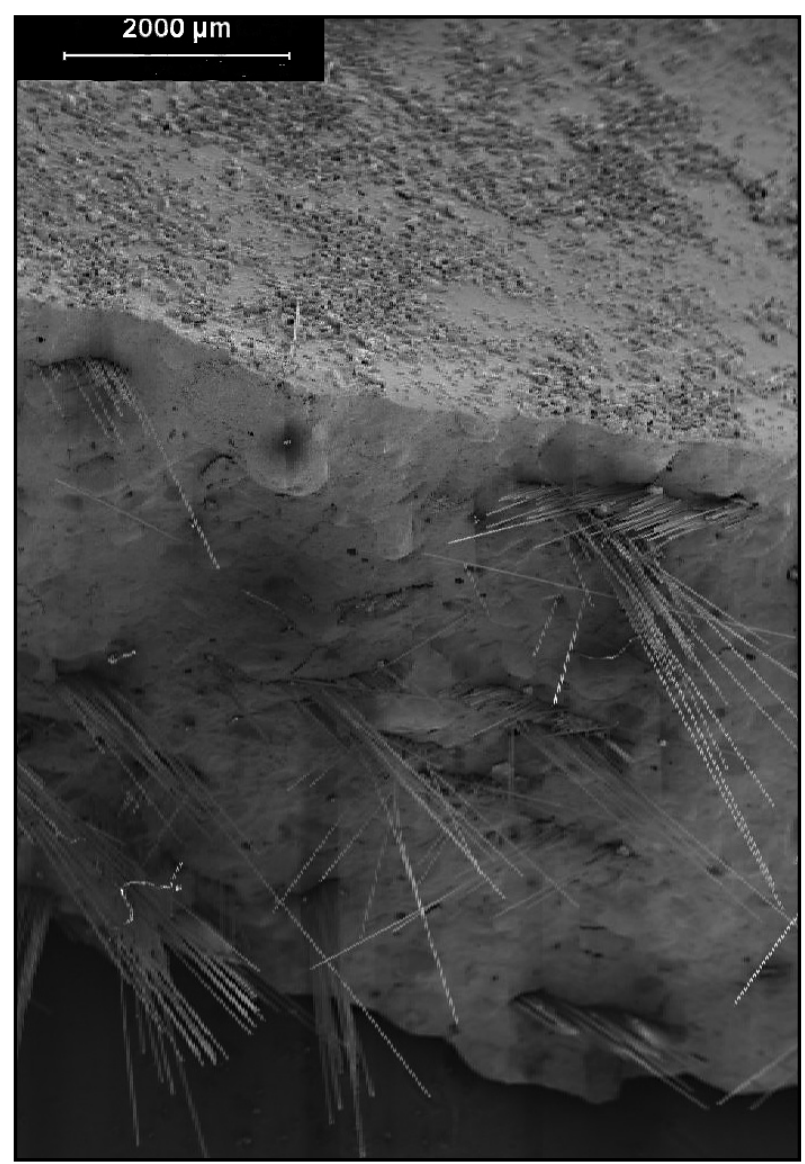

Figura 12. GRC con $10 \%$ metacaolín envejecido durante 40 días.

Figure 12. 40-day aged GRC with 10\% metakaolin.

The micrographs of the samples fractured after 80-day ageing are shown in Figures 13 and 14.

The features described for the 40-day aged specimens were found in the 80-day samples as well. The fracture surfaces were even smoother in the latter, which also had slightly more broken fibres. The test specimens with metakaolin had fewer broken fibres than the other formulations, while a smaller number of fibres had pulled out of the 80-day aged samples containing metakaolin than in the 40-day specimens with the same composition.

The specimens aged for 120 days confirmed the 40 - and 80-day GRC findings. 


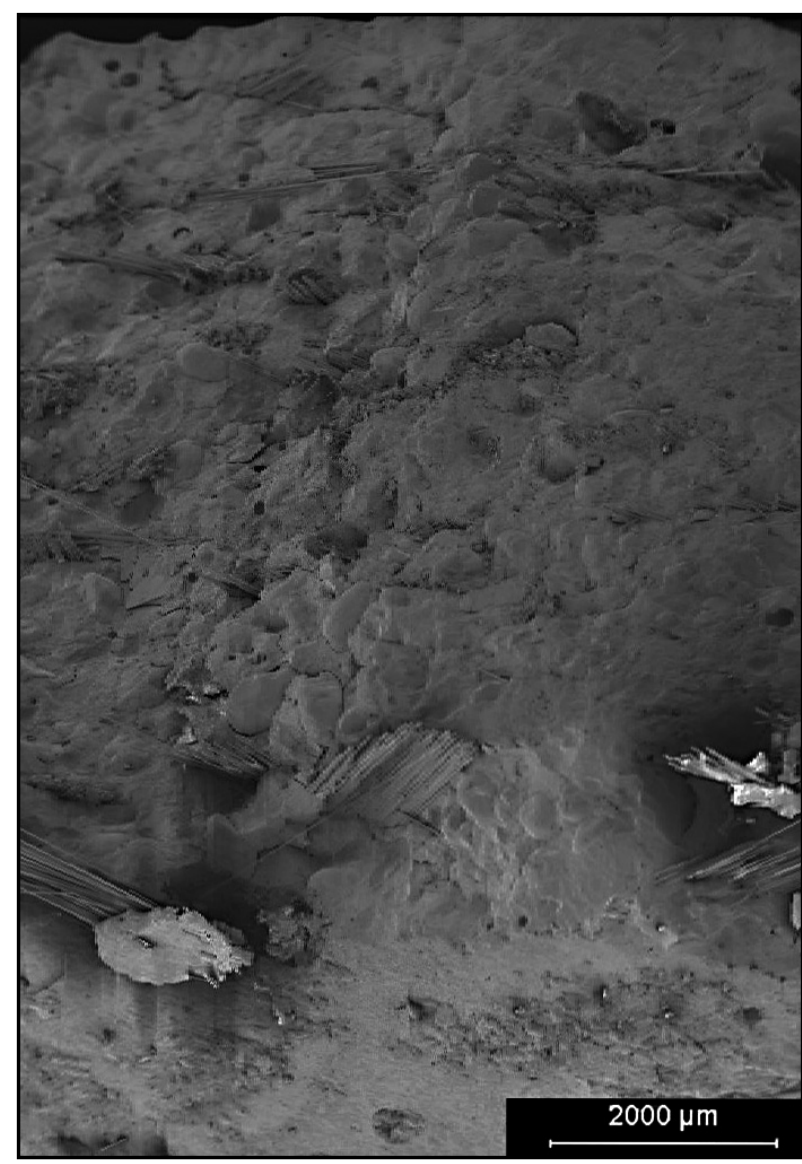

Figura 13. GRC con $10 \%$ humo de sílice envejecido durante 80 días Figure 13. 80-day aged GRC with $10 \%$ silica fume.

\section{ANÁLISIS DE RESULTADOS Y CONCLUSIONES}

El uso del GRC para la producción de elementos portantes requiere que el material mantenga sus buenas propiedades mecánicas, tanto la resistencia como la ductilidad del material, a largo plazo. Aunque el envejecimiento y fragilización del GRC con el paso del tiempo se puede considerar un problema resuelto mediante la adición de puzolanas como el metacaolín, las altas proporciones necesarias, superiores al $25 \%$ respecto del peso de cemento, incrementan el precio del material reduciendo su competitividad en el mercado frente a otro tipo de materiales. Esto hace que su uso industrial sea minoritario.

Este estudio analizó la posibilidad de lograr una reducción de los efectos de paso del tiempo en el GRC mediante la adición de pequeñas proporciones de humo de sílice o de metacaolín, que mantuvieran el coste del material en precios de mercado.

Sin embargo, los resultados obtenidos en los ensayos muestran cómo la adición de humo de sílice con proporciones hasta del $20 \%$ o metacaolín con proporciones de

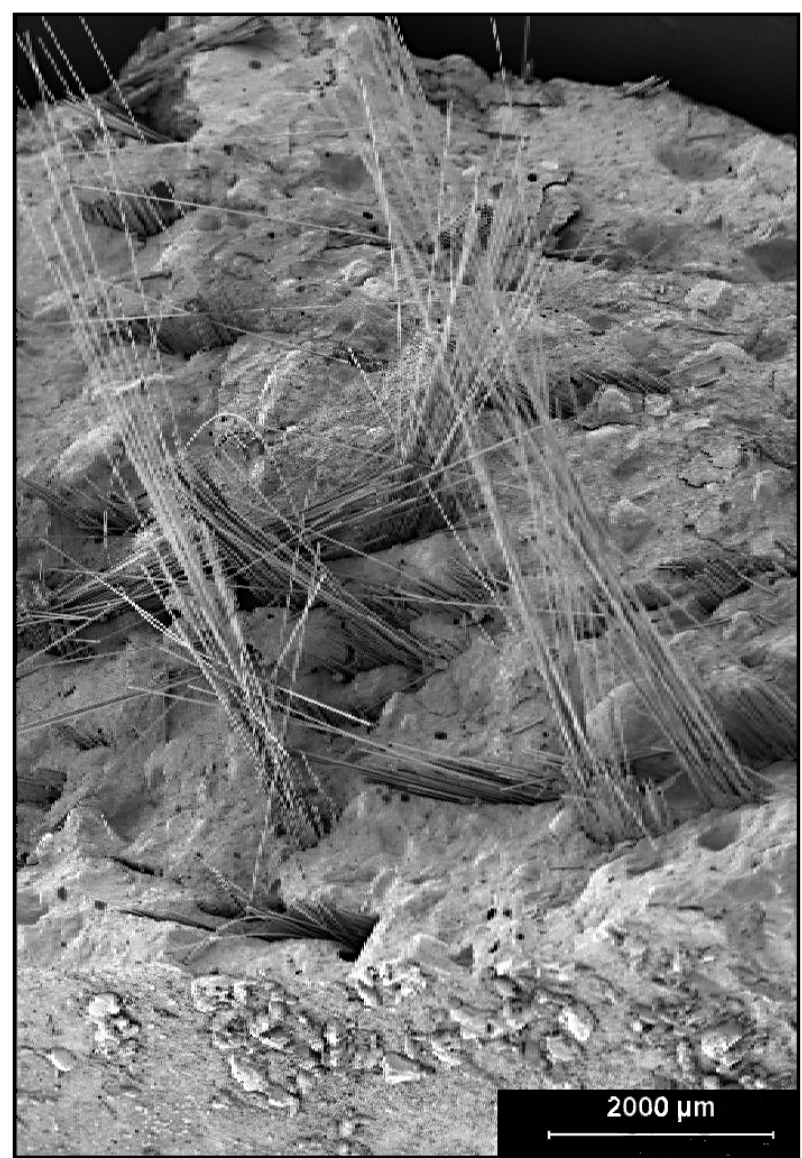

Figura 14. GRC con $10 \%$ metacaolín envejecido 80 días. Figure 14. 80-day aged GRC with $10 \%$ metakaolin.

\section{ANALYSIS OF RESULTS AND CONCLUSIONS}

GRC strength and ductility must be maintained over the long term if this material is to be used in the manufacture of load-bearing members. Although the addition of pozzolans such as metakaolin delays the ageing and embrittlement that occurs over time, the high proportions necessary (over $25 \%$ by weight) for such improvement raise the price of GRC, rendering it less competitive than other materials. As a result, it is scantly used in industrial applications.

The present research addressed the possibility of reducing the effects of ageing in GRC by adding smaller amounts of silica fume or metakaolin to keep costs within reasonable margins.

The test results showed, however, that additions of up to $20 \%$ silica fume or $10 \%$ metakaolin by weight are not effective in mitigating age-related problems, at least in 
$10 \%$ respecto del peso de cemento no son efectivas para reducir los problemas que se derivan del envejecimiento del material, al menos cuando se ha realizado un envejecimiento acelerado mediante inmersión en agua caliente.

El análisis de las superficies de fractura mediante microscopía electrónica de barrido se corresponde perfectamente con los resultados de las curvas tensión-deformación. En los ensayos con probetas a 28 días se observan superficies de fractura irregulares con haces de fibras arrancadas de la matriz lo que corresponde a un proceso de rotura por fisuración múltiple y buena ductilidad. Para probetas envejecidas, las fractografías son cada vez más regulares y lisas y el número de fibras rotas va creciendo. El material se comporta cada vez de una forma más frágil. El mecanismo de fragilización más plausible es por tanto la progresiva disgregación de los haces de fibras que quedan envueltas por productos de la hidratación del cemento, que a su vez las anclan a la matriz, disminuyendo el número de fibras arrancadas y aumentando el número de fibras rotas con muy poca deformación. Este efecto apenas se ve retrasado por la adición de metacaolín y no se ve afectado por la adición de humo de sílice.

Por lo tanto se puede afirmar que el uso de GRC para la producción de elementos portantes se ha de realizar con cautela. Si no se ha añadido al mortero de cemento una alta proporción de puzolana, el material sigue mostrando una pérdida de las propiedades mecánicas a largo plazo, asumiendo que el proceso de envejecimiento acelerado mediante inmersión en agua caliente es válido para predecir el comportamiento del GRC a largo plazo.

No obstante hay que resaltar que la resistencia y la ductilidad del material a largo plazo es mayor que la del mortero sin fibras. Por lo tanto la producción de GRC para elementos no estructurales es una buena solución ya que los esfuerzos que debe soportar el material son menores que los valores que resiste a largo plazo. Bajo estos condicionantes no son necesarias las adiciones y así los costes del material son razonables.

\section{AGRADECIMIENTOS}

Los autores quieren expresar su agradecimiento a SIKA y a los siguientes programas CICYT Project BIA 200407336. the case of accelerated ageing based on immersion in hot water.

A scanning electron microscopic analysis of the fracture surfaces corroborated the stress-strain curve findings. Tests on 28-day specimens showed irregular fracture surfaces with bundles of fibres pulled out of the matrix, associated with a ductile fracture process involving multiple cracking. The fractographs of experimentally aged specimens showed increasingly straight and smooth edges with time, along with a larger number of broken fibres, denoting the progressive embrittlement of the material. The mechanism that most likely governs this process is the gradual breakdown of the fibre bundles wrapped in the cement hydration products that anchor them to the matrix, with a decline in the number of detached whole fibres and a concomitant rise in the quantity of scantly deformed broken fibres. This effect is only marginally delayed by the addition of metakaolin and unchanged by the addition of silica fume.

GRC must therefore be used with caution in the manufacture of load-bearing members. If large proportions of pozzolans are not added to the cement mortar, GRC mechanical properties continue to deteriorate over time (assuming that immersion in hot water to simulate accelerated ageing is a valid method for predicting the long-term behaviour of this material).

Despite the foregoing conclusions, the long-term ductility and strength of GRC are greater than in fibreless mortar. Therefore, GRC can be used to advantage in nonstructural elements, in which the stress involved is lower than the long-term strength of the material. Under these circumstances, additions are not necessary and the cost of $G R C$ is reasonable.

\section{ACKNOWLEDGEMENTS}

The authors would like to express their gratitude to SIKA. This research was funded by the CICYT [Centre for Scientific and Technological Research] under Project BIA 2004-07336.

\section{BIBLIOGRAFÍA / BIBLIOGRAPHY}

(1) Young, J.: "Designing with GRC", Architectural Press, London, 1978.

(2) True, G.: GRC Production and uses, Palladian Publications Ltd., London, 1986. 
(3) Glassfibre Reinforced Cement Association: International Survey of GRC, use and development 1978/87, GRCA, Newport, 1989.

(4) Majumdar, A. J.; Laws, V.: "Glass Fibre Reinforced Cement", BSP Professional Books, Oxford, 1991.

(5) Stain, C.: "Architectural criteria for glassfibre reinforced concrete", GRC Proceedings 10th international GRCA congress, Strassbourg, October 1995.

(6) Muller, D.; Morrison, I. J.: "Recent developments in glassfibre reinforcement". In: Rossi, P., Precast Chanvillard, G. (eds.), Fibre Reinforced Concretes (FRC) BEFIP' 2000. RILEM Pub., 2000.

(7) Cian, D.; della Bella, B.: "GRC Precast elements for extra-light self-supportings floors in offices and residential buildings", GRC Proceedings 12th international GRCA congress, Barcelona, October 2003.

(8) della Bella, M.; Cian, D.: "Extra light GRC sandwich elements for roofing in industrial buildings", GRC Proceedings 12th international GRCA congress, Barcelona, October 2003.

(9) Ferreira, J. C.; Branco, F. A.: "Structural application of GRC in telecommunication towers". Construction and Building Materials, vol. 21 (2007), pp. 19-28. doi:10.1016/j.conbuildmat.2005.08.003

(10) Bentur, A.; Mindess, S.: "Fibre Reinforced Cementitious Composites". Elsevier Science Pub., New York, 1990.

(11) Bartos, P. J. M.; Zhu, W.: "Effect of microsilica and acrylic polymer treatment on the ageing of GRC", Cem. Concr. Comp., vol. 18 (1996), pp. 31-39. doi:10.1016/0958-9465(95)00041-0

(12) Mobasher, B.; Shah S.: "Test parameters for evaluating toughness of glass-fiber reinforced concrete panels", ACI Materials Journal, vol. 86 (1989), pp. 448-458.

(13) Shah, S. P.; Ludirdja, D.; Daniel, J. I.; Mobasher, B.: "Toughness-durability of glass fiber reinforced concrete systems", ACI Materials Journal, vol. 85 (1988), pp. 352-360.

(14) Qian, X.; Shen, B.; Mu, B.; Li, Z. "Enhancement of aging resistance of glass fiber reinforced cement", Materials and Structures, vol. 36 (2003), pp. 323-329.

(15) Peled, A.; Jones, J.; Shah, S. P.: "Effect of matrix modification on durability of glass fiber reinforced cement composites", Materials and Structures, vol. 38 (2005), pp. 163-171.

(16) Marikunte, S.; Aldea, C.; Shah, S. P.: "Durability of glass fiber reinforced cement composites: Effect of silica fume and metakaolin", Advanced Cement Based Materials, vol. 5 (1997), pp. 100-108. doi:10.1016/S1065-7355(97)00003-5

(17) Francois-Brazier, J.; Soukatchoff, P.; Thiery, J.; Vautrin, A. "Comparative study of the mechanical damage and durability of glass cement composites", Brittle Matrix Composites, vol. 3, (1991), pp. 278-289.

(18) Thiery, J.; Francois-Brazier, J.; Nautrin, A.: "High durability glass-fibre reinforced modified cementitious matrix", Fiber-Reinforced Cementitious Materials Conference, Materials Research Society, USA (1991), pp. 79-91.

(19) Thiery, J.; Genis, A.: "High durability glass cement composites: New Vetrotex Sistem". GRC Proceedings 7th international GRCA congress, Maastricht, September 1989.

(20) De Gutiérrez, R. M.; Díaz, L. N.; Delvasto, S.: "Effect of pozzolans on the performance of fiber-reinforced mortars", Cem. Concr. Comp., vol. 27 (2005), pp. 593-598. doi:10.1016/j.cemconcomp.2004.09.010

(21) Payá, J.; Bonilla, M.; Borrachero, M. V.: Monzó, J.; Peris-Mora, E.; Lalinde, L. F.: "Reusing fly ash in glass fibre reinforced cement: A new generation of high-quality GRC composites", Waste Management, vol. 27 (2007), pp. 1416-1421. doi: 10.1016/j. wasman.2007.03.014 PMid:17512718

(22) Van Itterbeeck, P.; Purnell, P.; Cuypers, H.; Wastiels J.: "Study of strength durability models for GRC: Theoretical overview", Composites: Part A, vol. 40 (2009), pp. 2020-2030. doi:10.1016/j.compositesa.2009.09.010

(23) Van Itterbeeck, P.; Cuypers, H.; Orlowsky, J.; Wastiels, J.: "Evaluation of the strand in cement (SIC) test for GRCs with improved durability", Materials and Structures, vol. 41 (2008), pp. 1109-1116. doi:10.1617/s11527-007-9309-y

(24) European Committee for Standardization (1998) EN 1170 Parts 1-7 Precast concrete products: test methods for glass-fiber reinforced cement, Bruxelles.

(25) Litherland, K. L.; Oakley, D. R.; Proctor, B. A.: "The use of accelerated ageing procedures to predict the long term strength of GRC composites", Cem. Concr. Res., vol. 11 (1981), pp. 455-466 . doi:10.1016/0008-8846(81)90117-4

(26) Ball, H. P.; Wackers, M.: "Long term durability of GFRC composites containing polymer". GRC Proceedings 10th international GRCA congress, Strasbourg, October 1995.

(27) Purnell, P.: "Interpretation of climatic temperature variations for accelerated ageing models", Journal of Materials Science, vol. 39 (2004), pp. 113-118. doi:10.1023/B:JMSC.0000007734.71945.93

(28) Purnell, P.; Beddows, J.: "Durability and simulating ageing of new matrix glass fiber reinforced cement", Cem. Concr. Comp., vol. 27 (2005), pp. 875-884. doi:10.1016/j.cemconcomp.2005.04.002

(29) Enfedaque, A.; Cendón, D.; Gálvez, F.; Sánchez-Gálvez, V.: "Envejecimiento y pérdida de propiedades en los morteros reforzados con fibras de vidrio (GRC)", Anales de Mecánica de Fractura 26, vol. 2 (2009), pp. 531-536. 